Work in progress: References, collaborations, food-related examples and additional ideas are welcomed

\title{
Food as a commons: Reframing the narrative of the food system
}

Towards sustainable food as a universal basic entitlement: rebalancing property rights, the public domain and the commons.

\section{Jose Luis Vivero Pol}

Centre for Philosophy of Law, Université Catholique de Louvain (http://biogov.uclouvain.be/) Jose-luis.viveropol@uclouvain.be

Primum vivere, deinde philosophare Anonymous

An old error is always more popular than a new truth

German Proverb
"Don't you remember the rule we had when we lived with you? If you don't work, you don't eat." St. Paul's letter to the Thessalonians 3:10

What is common to many is taken least care of, for all men have greater regard for what is their own than for what they possess in common with others

I do not expect to see the fruits of this paper in my lifetime,

but my grandchildren may, hopefully.

James Quiligan 


\section{Summary}

Our body demands food (calories), water (liquid) and air (oxygen) to keep its vital functions. Those are the only natural inputs, perhaps with sunlight, that are compulsory to live and nevertheless their economic nature is rather different for each one. Food has evolved from a common good and local resource to a national asset and then to a transnational commodity and the commodification process is rather completed nowadays, dating back from the origins of agriculture. Cultivated food is fully privatized although wild edible animals and plants are still considered commons. Being considered a private good means that human beings can eat food as long as they have the money to but it or the means to produce it, with some of those means also considered as private goods (land, agro-chemicals) although not all (seeds, rainfall, agricultural knowledge). Therefore, no money, no food and that is why hunger still prevails in a world of abundance.

Water was largely considered a common good up to mid XX century, when the process of privatization initiated in parallel to the growing demand. Expected demand for water will certainly outpace the availability and the replenishment rates in the near future. Air is so far considered a global common good as current human demand is much lower that availability and the replenishment rates. However, incipient privatisation processes have already started, with the carbon sequestration schemes and the tradable $\mathrm{CO} 2$ emission bonus being at the forefront.

Although cultivated food is not regarded as a common good, several food-related elements are already widely considered in such a way (i.e. fish stocks, wild fruits, cuisine recipes, agricultural knowledge, food safety regulations and genetic resources). Cultivated food is hence a private good although its original consideration, means of production, implications (hunger) and benefits (public health and good nutrition) can be considered as common goods. One of the most important food-related implications is the food and nutrition security of humanity and this paper is based on the rationale that Global Food and Nutrition Security can also be considered a global common good.

In order to provide a sound foundation for the transition towards sustainable food systems, the very nature of food as a pure private good needs to be contested and subsequently reversed. In that sense, this paper proposes a re-conceptualisation of food as a common good, a necessary narrative for the redesign of the dominating agroindustrial food system. This aspirational transition shall lead us to a more sustainable, fairer and farmer-centred food system where every human being can eat enough and adequately to have a meaningful and healthy life. The idea of the commons is applied to food, deconstructing food as a private good and reconstructing it as an impure commons that can be better produced and distributed by a hybrid tri-centric governance system compounded by market rules, public regulations and collective actions.

Should food and food security be consider as common goods, the implications for the governance of the Global Food System would be enormous, with examples ranging from placing this global common good outside the framework agreements dealing with pure private goods (i.e. the WTO Doha Round), banning financial speculation on food commodities or preparing an international binding agreement to govern the production, distribution and access of food to every human being with minimum amounts to be free from hunger. 


\section{1.- Introduction: the multiple dimensions of food}

What does food mean for human societies in the XXI century? A difficult question with no straightforward response, although there seems to be some common features that accompany the definition throughout societies. Food is clearly a basic human need as our body demands food energy to keep its vital functions and that is why it is included at the very bottom of Maslow's hierarchy of needs (Maslow, 1943). Additionally, none can deny the importance of food as a foundational pillar of culture and civilizations (Fraser \& Rimas, 2011; Diamond, 1997). Everything having to do with food such as its collection, capture, cultivation, preparation and consumption represents a cultural act (Montanori, 2006). In modern times, most human needs have been framed as legitimate rights to which citizens can aspire, and which society at large has an obligation to respect and provide for. Those rights in turn became the legitimate and legal framework for political and social action in modern nation-states (Stavenhagen, 2003), and hence food was also considered a human right recognized under international law. The right to food protects the right of all human beings to feed themselves in dignity, either by producing their food or by purchasing it, as enshrined in Article 25 of the Universal Declaration of Human Rights (United Nations, 1948) and the Article 11 of the International Covenant on Economic, Social and Cultural Rights (United Nations, 1966). The latter Covenant, a binding agreement, also stipulates the fundamental right of everyone to be free from hunger and details what States individually and collectively must do to fulfill this obligation.

But, food dimensions do not stop here, as food is also a commodity, and the food industry is one of the biggest areas of economic activity worldwide, representing around $10 \%$ of the global gross domestic product (Forbes, 2007) and being one of the major and more consistent contributors to growth of all economies. The food industry, which comprises farming, food production, distribution, retail and catering, was valued between \$4.2 and \$5.7 trillion in 2008-09 (Alpen Capital, 2011, IMAP, 2011 citing data mining private companies such as Datamonitor and Euromonitor) and it is expected to increase to $\$ 7$ trillion by 2014 (IMAP, 2011). The global food import bill for 2011 alone was an astonishing \$1.3 trillion and international agricultural prices will remain significantly higher than precrisis levels for at least the next decade (Wise \& Murphy, 2012).

Wal-Mart, a food retailer, used to be the biggest private company in the world, now being displaced to the third position, with gross benefits and actives that clearly surpass most of sovereign states. As a commodity, food trade is regulated by the WTO framework, an international institution not bound by the UN charter and thus with less legal constraints to respect, protect and fulfill the human rights. Moreover, the food industry is subject to a concentration process that is leading to a system where just a few dominant and too-big-to-fall transnational companies are getting a decisive hand in all steps of the food chain, from the farm to the table (ETC Group, 2009; Clapp \& Fuchs, 2009; Weis, 2007). There has been an almost complete commodification and marketization of the food production system, with globalization exacerbating the widening of food chains. That means more food miles, reduced food options to those that are able to cope with transport hurdles and stay attractive to customer and all-the-year presence of seasonally produced foods. Food travels a lot in order to yield profit for the intermediaries or "coyotes" as they are called in Latin America (Murray, 2007). On the way, we lose or waste one third of all the food produced every year, what roughly means 1.3 billion tonnes of food per year, enough to feed 600 out of the 868 million hungry people we have in 2012 (Stuart, 2009, FAO, 2011).

This reduction of food dimensions to the one of a commodity explains to many authors the very roots of the failure of the global food system, a system that produces food in excess to adequately feed the whole planet but it is not capable of guaranteeing equitable food access to everybody by simply using the market rules (Magdoff, 2012).

\section{2.- The unsuccessful food system is evolving}

Since the outbreak of a global financial crisis in 2008, accompanied by extraordinary commodity price spikes, growing financial speculation in food commodities and massive land-grabbing deals between 
transnational companies and land-rich but least-developed countries, food and hunger are definitely high on the global agenda. Developments around food, climate, energy and finance in the last two decades have pushed questions on food security and nutrition back into the centre stage of development. More and more, it seems evident the prevailing food system must be reinvented as it has failed to fulfil its basic goals: feeding people in a sustainable manner and avoiding hunger. The persistence of high levels of hunger and malnutrition as well as the dramatic growth in the incidence of overweight and obesity are clear examples of how the weakly state-regulated food systems are operating mainly to maximize the profit of food enterprises instead of maximizing the nutrition and health benefits food provide to all of us. Globally speaking, we eat badly, produce food in a rather unsustainable manner and consider food merely as a commodity, neglecting its dimensions as a human right, a basic human need or a major pillar of cultural identification. More than half the world eat in ways that damage their health, and hunger and obesity are at the forefront of contemporary debates. The global food system is not fulfilling its core mandate and there is a need to bring unconventional and radical perspectives into the debate on possible solutions. This is all the more urgent because food production is increasingly threatened by climate change, globally stagnant crop yields, diminishing water, soil and agro-biodiversity resources, and the current energy and economic crises. The superb IAASTD report concluded that unless agriculture, and the way society engages with food, agriculture, livestock production and fisheries, is fundamentally changed, it will not be possible to feed the projected 9 billion world population, ensure equity and sustain the planet (IAASTD, 2009)

Despite years of international anti-hunger efforts and rising gross national incomes and per capita food availability, the number of hungry people has been reduced at a very slow pace since 2000 (only 49 million in 12 years, what means 4 million hungry people less per year) and we are still 868 million undernourished people in the world (FAO et al., 2012), with absolute figures of hungry people mounting in developed countries, the Near East and North and Sub-Saharan Africa. These relatively poor results in the fight against hunger, overshadowed by the huge reductions in China, contrast with the apparently successful actions against poverty reported by the World Bank (Ravaillon, REFERENCE NEEDED). To make things worse, the 2008 and 2011 food price crises pushed 153 million people into extreme poverty and hunger (World Bank, 2012). At present, an estimated 148 million under-five children remain undernourished in developing countries (De Onis et al., 2011) although developed countries host also a growing number of hungry people (i.e. more than 45 million people are already receiving food assistance through Federal programs in 2011, USDA REF). Nine out of ten of the 19 million most severely malnourished children remain untreated (ACF-MSF, 2009) as there is no money to save their lives (UNICEF, 2011). And, contrary to common belief, most deaths do not happen in acute emergencies, but occur on a daily basis as a result of chronic hunger in relatively stable and middle-income countries (Gross \& Webb, 2006). Hunger is the largest single contributor to mortality worldwide, causing $35 \%$ of total under-five year old deaths. With millions of people needlessly dying prematurely each year from hunger in a world of ample food supplies, nobody can dispute the need for a change.

On the other side, more than 1450 million people worldwide were overweight in 2008, with a bodily mass index $(\mathrm{BMI})>25$, out of those at least 500 million are obese, with BMI >30 (Stevens et al., 2012). Overweight and obesity cause, worldwide, 2.8 million deaths (WHO, 2011), and the trends are rather worrying for the years ahead, with expected figures of 2160 million overweight and 1120 million obese people by 2030 (Kelly et al. 2008). And last but not least, micronutrient deficiency or hidden hunger affects to more than half the population of the world (De Schutter, 2011). The fact that there has been so little headway made in cutting these three manifestations of bad nutrition, in spite of the fact that their dangers are well understood and that quite simple solutions exist, implies an structural failure in the current dynamics, ethics, institutions and governance of the food system that feeds the world. And all this happens despite bountiful harvests and soaring profits for the transnational corporations that dominate global food trade.

Globalized food and energy transnationals, combined with some wealthy but poor-resourced economies, have targeted food, water, land and genetic resources as the new key resources in the global capitalist rush for maximising profit and minimising costs, triggering a renewed process of 
privatisation, commodification and physical enclosure of commons. This new cycle of resourcegrabbing is termed as a new colonialist approach to the Global South, and the major drivers are not only the quest for additional food for citizens, but the quest of additional natural resources to produced biofuels, to export drinkable water, to crop feed for livestock or to cultivate more patented GMOs used as cash crops (soybean or cotton). Less than $40 \%$ of the new land-grabbing deals settled since 2000 are currently cultivating food for humans (OXFAM 2012 report on land grabbing). The relevance of this neoliberal rush on declining natural resources is that it may open a new path in the current transition the global food system is vividly involved. And not for good, of course.

\section{3.- Where is the current food transition leading us to?}

Broadly speaking, nature and globalised human societies are experiencing a transition pattern that unfolds from diversity to uniformity, from complexity to homogeneity and from richness to impoverishment. That impoverishing transition is well documented in nature (ecosystems, species: Carpenter \& Bishop 2009), culture (languages, food diets, songs: Gorenflo et al. 2012; Prescott-Allen \& Prescott-Allen, 1990; Serra et al. 2012) and economy (enterprises, media: Shah, 2009). The globalizing trend is leading a transition towards a less diverse world.

In that scenario, food transitions have been common to human societies since the domestication of wild crops and the origins of agriculture (Fernandez-Armesto, 2002). Actually, in the last 300 hundred years two transitions have been documented in western societies (Fogel, 2008; Popkin, 2003; Bengoa, 2001), as well as in Asia (Chen \& Xu, 1996). Some of them have been fast and violent processes, such as the introduction of new crops from the Americas, while on other occasions they have undergone slowly. In any case, the different food transitions were always accompanied by new laws supporting the privatization processes and legal struggles and court cases (Nuijten, 2006). At present, the globalised world is at the crossroad of two food transition trends: the well advanced nutrition transition from vegetable- to meat-dominated diets (Popkin, 2003) and the incipient food transition from oil-based industrial agriculture to more sustainable and local food systems (Heinberg \& Bomford, 2009). The dietary transition to higher meat and processed food consumption and a drop in the intake of cereals, legumes, fruits and vegetables will increase the water and carbon footprint, as already portrayed for Spain and its Mediterranean diet (Lopez-Gunn at al., 2012).

The path selected by the majority of the population and the new food paradigm that will emerge from this transition will greatly affect our survival within the Earth's carrying capacity. With our current insatiable appetite for natural resources and the highly-polluting development pushed by the neoliberal economic model, the human society has already overstepped three out of nine interlinked planetary boundaries (rate of biodiversity loss, climate change and human interference with the nitrogen cycle), defined as enabling conditions for human development (Rockstrom et al., 2009).

Under the combined effect of changing lifestyles and the concentration and liberalisation of the food industry, the mass industrial food model, which is becoming dominant, is increasingly failing to satisfy the sustainability criteria that should characterise the global food systems, namely producing food for all in an economically and socially fair way, while preserving the environment, promoting healthy diets and maintaining cultural diversity.

Nevertheless, all previous transitions share a common denominator: food always bears the same consideration as a private good that is produced by private means and traded in the market. Market rules and the purchasing power are the main forces to match demand and offer of such a basic stuff. None of the most relevant analysis produced in the last decades on the fault lines of the global food system and the very existence of hunger has ever questioned the nature of food as a private good, produced by private inputs or found in enclosed areas in the wild (FAO, 2012; IAASTD, 2009; UK Government, 2011; UN, 2005; UNEP, 2009). All researchers and policy makers implicitly admit that food is purely a private good, that you gain access to as long as when you have enough money to purchase it in the market or produce it yourself with other privately-owned inputs. Along those lines, everyone asserts that the main problem nowadays is the lack of food access, although food production 
concerns are also gaining momentum (FAO, 2012; World Bank, 2008; MDG and WFS Plan of Action, G-8 Gleanegles and G-20 L'Aquila, CFS). However, several dimensions of food production and consumption are yet considered as commons, such as the genetic resources, the cooking recipes and wild foods and fish stocks, and we will develop those dimensions later in the paper.

Treating food as a private good implies that food is produced and distributed in accordance of the purchasing power of each individual, provided that this purchasing power is enough to guarantee the minimum amount of calories required by our body. These caloric requirements are unique for each person, depending on his body needs, physical activity, weather conditions and ethnic considerations, but these requirements are also absolute: they cannot either be negotiated with our body nor vary depending of the relative abundance of food. The food thresholds for adult human beings are on average established on $2200 \mathrm{Kcal}$ per person per day. That is why hunger is an absolute need whereas poverty is a relative measure, depending on the purchasing capacity of any given unit and the relative wealth of the others (i.e. inflation proves how artificial is the money of one currency, as one person with ten dollars a day can be considered well off in Haiti and poor in Switzerland).

\section{4.- The three essentials for human life and its consideration as private-public goods}

Adequate and nutritious food, fresh and pure air and drinkable water are three essential and regular inputs produced by Earth our human body requires to functioning: oxygen from air to keep cell processes, the calories, proteins and vitamins from the food to provide energy in form of Adenosin Tri-Phosphate and building blocks to keep us alive, and water required to maintain the body hydration and as a solvent for vitamins, amino acids and nutrients. From a human perspective, the commons are those goods essential for the survival of each and every human being and food, water and air perfectly fit that definition.

Air, food and water are widespread on the Earth and easily available. The three essentials are limited, as the Earth is finite, but renewable resources, and they are produced by nature in a cyclical process. Food and water used to be freely available until the domestication of crops and livestock, when property rights began to be established. As they are key elements for our survival they can be considered as fundamental human rights, closely linked to the most fundamental one: the right to life. In that sense, they should be guaranteed to each and every one. Actually, food is a human right since 1945 and more precisely defined since 1963; water has been recently upgraded to such category by the UN General Assembly in 2010 (United Nations, 2010), whereas air is still so abundant and accessible that has not yet being even considered as a right or as an exploitable natural resource.

\section{Food}

Food can be cultivated (crops, fish ponds, livestock) or harvested from nature (hunting, fish stocks, wild fruits and vegetables). Food produced by nature can be considered a public good (fish stocks or genetic resources are so considered), but the consideration of cultivated food as a public good is still more controversial and basically out of discussion. Cultivated food is a private good and private producers have an incentive to produce it as they can prevent non-payers from accessing it. Therefore, food is subject to trading, stocking and oligopoly control, and that social construct opposes radically to the consideration of food as a human right that should be guaranteed to all.

And yet, food was considered a common good during the hunting gathering period. Then, during the domestication of crops and livestock, a legal and physical appropriation of cultivated food as a private resource took place, although hunting, wild fruits, sea fruits and fish stocks in the sea, rivers or lakes were still considered as common goods. The privatisation of production brought as well the privatisation of food products, although enabling means for food production, such as genetic resources and water remained public. Not land though. Nowadays, however, most food is considered a private good, and therefore excludable and rival. Food is highly commoditized and its production, harvesting, manufacturing and distribution are gradually concentrated in few private consortiums, that all together control a big share of total food produced in the world. 
We are witnessing a complete commodification of nature (ETC Group, 2011) and a concentration of world agri-food chains in few companies controlling most of the food we eat. Nevertheless, nowadays, several types of food (wild fruits, fish stocks) are yet legally owned in common, as they belong to state-owned lands or internationally-managed oceans. And over 2.5 billion people live in and actively use the Earth's forest and drylands, most of them classified as public lands. Grazing and fishing grounds in most traditional societies have often been commonly held and managed quite sustainably for centuries. This was achieved by means of informal social restraints and traditions which prevented overexploitation (Goodstein, 1995:34)

The public-good nature of food can be seen in its many public-good components. While nutritious foods and healthy diets can be rival and exclusive (private goods), their insufficiency can create significant consequences for public health (a public good), through increased social and economic costs of malnutrition and diet-related illnesses such as diabetes and heart disease (Caraher \& Coveney, 2004; Haddad, 2003). Healthy food is not only a pillar our physical life and a key determinant to our health, there is also a direct link between the consumption of healthy food, mostly fruit and vegetables, and the humans' psychological well-being (Blachflower et al. 2012).

From a utilitarian point of view, food as a global commons could be thought of as "the greatest possible amount for the greatest possible number of individuals", what is commonly coined in marketing terms as "enough food for all". From the legal point of view, and using the fundamental right to be free from hunger, the least consideration of food as a global common could be translated into the minimum amount of food for the maximum amount of people, considering the minimum a quantity that prevents from suffering hunger, although not the ideal in quantity and quality to be considered food secure.

Although food is still regarded as a private good, several authors are already proposing the consideration of Food and Nutrition Security (FNS) as a public good (Rocha, 2007; De Schutter, in press). All individuals living in a food-secure society benefit from that condition even if they were not contributing or paying for its provision. In other words, food security can be simultaneously enjoyed by many people (a public good), in contrast to private goods which are marked by rivalness in consumption and for which property right enforcements prevent consumption if one does not pay (Ver Eecke, 1999).

\section{Water}

All along history while available water resources were exceeding human needs, water was considered as a global public good. Water cannot be produced by human means, only extracted, transported and consumed, as well as polluted or cleaned. Water is partially privatized, or in the process in many countries, although it is still freely available in rivers, lakes and wells, although not always drinkable. Since the very moment human needs overpassed the easily available water supplies, water started to be highly appreciated as a valuable resource, and therefore subject to be priced. The monetisation of water is triggered by its scarcity and the profit opportunity for companies able to secure and manage the supply. International institutions such as the World Bank or private companies such as Suez are frontrunners in this race to finally privatize every drop of water. Water is in the process of being rebranded from a common good to a club good, a first step towards a general consideration as a fully private good, following a very similar path to that of food (REFERENCES). The consideration of water as a commons is gradually evolving (REF) as long as its enclosure and commodification is progressing (Barlow, 2007). Huge monopolies exist within the global water industry with two French water corporations, Vivendi and Suez, dominating about $70 \%$ of the world water service market (Polaris Institute, 2003). In Spain, 80\% of the private water supply sector (already representing half of total water consumed) is controlled by two companies (Aquagest and Aqualia), functioning de facto as a pure oligopoly (Publico, 2013).

\section{Air}

Air is still considered a global public good and it has barely been enclosed although its commodification has already started. Air is a free resource found everywhere on the Earth's 
atmosphere, non-excludable but rivalrous. As there is plenty for every human being, we do not have to worry yet about its access or control. The carbon market (Emission Trade Scheme) and the agriculture emissions offsetting schemes used by the Clean Development Mechanism are to creative ways of enclosing the atmosphere and the anthropocene, by using creative accounting based on economic valuation of environmental processes, such as the flawed approach to soil carbon sequestration. The carbon market is quite speculative and deeply flawed, as there is an artificial oversupply of carbon credits that is plundering the prices.

\section{Box 1: Pure Air and pollution}

Not all available air is breathable and air pollution is becoming a serious health and environmental problem. Air pollution causes serious respiratory diseases such as asthma, chronic obstructive pulmonary disease, cardiovascular disease and lung cancer. More than 90\% of spanish citizens are already breathing unhealthy air, according to WHO standards. In the European Union, over 400,000 deaths can be attributed to polluted air, with 20,000 in Spain, and air pollution represents in Spain between 1.7-4.7\% of GNP (Ecologistas en Accion, 2012). Many city dwellers do not have the right to breathe a pure clean air (The Jamaica Observer, 2011), and as long as air pollution is growing in parallel to the re-industrialization of developing countries and emerging powers, pure air will be more valuable and therefore will start to be sought after.

\section{5.- The meanings of the commons to people, economists and politic makers}

\section{Commons for the people}

In the popular meaning, a common good describes a specific resource that is shared and beneficial for all or most members of a given community. Commons are owned in common or shared among communities. Commons also represent needs that go unmet, either by markets or by institutions. Public goods are deemed desirable by the public (Hampson \& Hay, 2004), as they generate tremendous benefits to society and presume a legitimation of governmental activity (Ver Ecke, 1999). Behind the commons is the fundamental idea that life is not for sale. Global public goods are public goods with benefits that are strongly universal in terms of countries, peoples, and generations. Examples of commons include fresh air, knowledge, lighthouses, national defence, flood control systems, street lighting, avoiding financial instability, clean environment, a legal justice system, universal public health, social security and peace. Environment and climate may be the ultimate examples of a global commons, meaning something that is shared across borders, across generations, by all populations, and that all depend on to thrive (Kaul \& Mendoza, 2003). Most global public goods were originally considered as national public goods that, in the wake of globalization, have gone global.

\section{The economic concept of public goods}

Standard economic theory distinguishes between two main categories of goods: private goods and public goods. Private goods are goods that are rival in consumption and excludable or singled out, so clear property rights can be attached to them. Public goods, by contrast, are goods that are nonexcludable, meaning that the goods' effects (benefits or costs) are shared by everyone. A pure public good is an extreme case of a positive externality. There is, in general, no profit motivation to lead private firms to supply a socially efficient quantity of such goods. In many cases, markets for public goods will not even exist (i.e. pure air). The excludability and rivalry properties that economists use to classify goods will be extensively discussed later on in the paper with regard to food.

\section{Box 2: The tragedy of the Commons: Hardin vs Ostrom}

According to the classic economic theory, the most usual problem created by common-property resources is the tendency for them to be overexploited to the point of exhaustion or extinction, if there is free and open access to them in which people not paying for the good may continue to access it (Hardin, 1968). Throughout the world, natural fisheries, common grazing pastures, forest resources and bio-piracy are also examples of open-access resources prone to the tragedy of the commons. In North America, recent problems with salmon and lobster fishing illustrate situations in which common-property resources in food production are involved (Rocha, 2007).

Some public goods may be subject to excessive use resulting in negative externalities affecting all users. Fish in the oceans and mushrooms in the forests are renewable resources in that their stocks can be replenished as long 
as the rate at which they are harvested is lower than the rate at which they can reproduce themselves. The problem with free, open-access common resources is that they tend to be harvested at a faster rate than they can naturally replenish themselves. Without controls, each resource taker has an incentive to take as much and as fast of this common resource as it can.

The Hobbesian solution portrayed in the Leviathan (Hobbes, 1651) acknowledges human selfishness and the subsequent trend to free-riding and thus the only possible solution to govern the commons and avoid its tragedy is through a centralised state and its regulatory force of public ownership. On the contrary, the Lockean solution assumes that common property prevents the optimal use of a good as no incentives are provided to keep and care for it and only fully privatised ownership can work. However, private property is not the only (or the most practical, or fair, or effective) way of dealing with this externality problem. So far, the debate on the best governance of common goods was circumscribed to the state or the market, but Elinor Ostrom offered a third model: one of emergent localised polycentric governance of complex economic systems (Ostrom, 2009).

The economic concept of public goods should not be confused with the expression "the public good", which is usually an application of a collective ethical notion of "the good" in political decisionmaking. Another common confusion is that commons are goods provided or to be provided by the public sector. Although it is often the case that the Government is involved in producing commons, this is not necessarily the case. They may be produced by private individuals and firms, by non-state collective action or they may not be produced at all. Additionally, the commons contains public property and private property, over which people have certain traditional rights.

\section{The political concept of the global public goods}

The notion of global public goods emerged a decade ago in the work of the United Nations Development Programme (UNDP) to highlight the need for greater cooperation across States in a context of increased interdependencies (Kaul et al., 2003). Global public goods are goods whose benefits or costs are of nearly universal reach or potentially affecting anyone anywhere, and they are public in consumption (Kaul, 2013). They are universal in that all actors can benefit from their production; non excludable in that no actor can be denied their benefits; and non-rival in that the cost of a good does not go up with additional consumers. They are the building blocks of different civilisations (Wolf, 2012). Public goods can only be obtained through politics: the politics of consensus building, collective participation, transparent decision making and democratic commitments, inspired by the values of freedom, justice and morality (Stavenhagen, 2003). The commons contain many of the keys to move towards a social model that is sustainable and based on principles of social justice, as they do not either operate strictly under the logic of private property or under state hierarchy.

Global Public Goods are provided at national level by governments, such as public health, economic stability or the road network (Brousseau et al., 2012), and at international level they are naturallyproduced (genetic resources, atmosphere, stable climate) or man-made produced (internet, financial stability), being regulated in some cases by semi-sovereign international institutions: i.e. the ISO regulatory framework or the Codex Alimentarius.

The tragedy of the commons in economic terms is rebranded as social dilemmas in the political sphere (Kaul et al., 2003), since all those who benefit from the provision of a local public good find it costly to contribute and would prefer others to pay for the good instead. If everyone follows the selfish dominant strategy, then the good is not provided or is underprovided. Yet, everyone would be better off if everyone contributed. In those situations of social dilemmas, institutions introduce a certain level of collective constraint, whether through formal or informal rules (such as social norms and intrinsic preferences), with the aim to produce better outcomes (Ostrom, 2005). Another political dilemma rather relevant these days is that "public" no longer means the communities who manage their local resources, but the central governing authority who controls these resources. In theory, public still means people; in practice, public means government decoupled from the people's social/ecological rights to their common goods (Quilligan, 2012). 
In this paper, we will be using pure public goods and commons as interchangeable terms, the former being mostly used in the economic realm and the latter being predominant in the sociological and social sciences domains. In both economic and political terms, food is an essential resource that requires management as a social mandate in order to guarantee the right to food for all. And food and nutrition security (FNS) could be considered a global commons or global public goods as it is beneficial for the community, the nations and the planet in general. FNS is not rivalrous (my own food and nutrition security does not prevent you to have yours) but it is definitely excludable (as we can see at present, with over 860 million people with no food security at all) although ethically abominable.

\section{6.- Revisiting the excludable and rivalrous filter for food: social constructs can be modified}

Although the literature on public goods is extensive and diverse, there is a standard economic definition of public goods anchored on non-rivalry and non-excludability. A public good (a commons) is a good that is both non-excludable and non-rivalrous in that individuals cannot be effectively excluded from use and where use by one individual does not reduce availability to others. Private goods cannot be enjoyed simultaneously by many people, and individuals can be prevented from using them. Exclusion mechanisms may include excessive pricing or patents. Pure public goods are usually provided by the government and financed from tax revenues. Different funding options result in different economic outcomes in terms of the distribution of the cost burden between taxpayers and users of the good or service.

Samuelson (1954) described non-rivalry as one of the two defining characteristics of a public good. Rivarly refers to the extent to which the use of a good by one person precludes its use by someone else. A good that is non-rivalrous can be used by an additional person without reducing its availability to others. Samuelson also mentioned that the marginal cost of producing one additional item is zero: it does not cost anything when, in addition, other persons consume the good. In strict economic terms, food is rivalrous: if I eat a peach it is no longer available for others to eat. However, peaches are continuously produced by nature (wild peaches) and by human beings (cultivated peaches), so it is no longer restricted in number as there is no a finite number of peaches on Earth. As long as the replenishment rate outpaces the consumption rate, the resource is always available and food is considered a renewable resource with a never-ending stock such as air. This renewal characteristic could play against the rivalrous consideration, as there should be always food, either produced by nature or cultivated. Food produced by nature and harvested in a sustainable way seems to be unlimited, available worldwide and enough for all human beings. Therefore, the food I eat would not prevent others to eat food, although they could not eat the same piece I already ate, as there is available food for everybody in practical terms.

Excludability means that it is possible for one person to prevent someone else from using the good. Usually whether or not a person consumes the good depends on whether or not he pays for it. Excludability is usually determined by ownership or property rights (Sands, 2003), as the owner of a good can limit access to it. According to Ostrom, excludability is the ability of producers to detect and prevent uncompensating consumption of their products (Ostrom \& Ostrom, 1977), but this feature cannot be applied to wild foods. In that sense, the debate on who owns nature-made wild food is rendered pivotal to understand the proprietary rights of food. Economists also say that because its nonexcludability, public goods get under-produced or under-accesed, and that idea fits well with wild food and human demand. The degree of excludability and rivalry depends on the technological nature of the good and the definition and enforcement of property rights. Theoretically speaking, food is also excludable as we can prevent anyone to get access to food, either by physical terms or by pricing it at unaffordable costs. However, should that food exclusion be done in absolute terms, that person would die of starvation, and thus it would eliminate the subject to whom the good, either private or public, is related to. In other words, the game would be over. One could argue that currently most foods have a price in the market, and that price deters many people to freely access to food. Although true, this is a superb example of a social construction that can be modified by social norms: proprietary rights are nothing but a set of social and legal norms, whose nature and specificities are determined by each society. Many societies have considered, and still consider, food as a common good (REFERENCES 
NEEDED), as well as forests, fisheries, land and water, and the consideration different civilisations and human communities have assigned to natural resources is rather diverse and certainly evolving.

Therefore, the main features that traditionally have been assigned to food (excludability and rivalry) can be contested, or at least revisited. In that sense, it is worth mentioning that both properties are neither ontological to the goods nor permanent, but mostly social constructions whose nature evolves along time. The main reason is that society can modify the (non)-rivalry and (non)-excludability of goods that often become private or public as a result of deliberate policy choices (Kaul \& Mendoza, 2003). That has clearly happened to food, it is currently happening to water and it will certainly occur to air. But the privatizing trend can be reversed and the rivalrous/excludable features of food can thus be modified if the society so considers.

\begin{tabular}{|c|c|c|c|}
\hline & & \multicolumn{2}{|c|}{$\begin{array}{l}\text { Rivalry } \\
\text { the property of a good whereby one person's use diminishes other people's use }\end{array}$} \\
\hline & & Low & $\begin{array}{ll}\text { High } \\
\end{array}$ \\
\hline \multirow[t]{2}{*}{$\begin{array}{l}\text { Excludability } \\
\text { the property of a } \\
\text { good whereby a } \\
\text { person can be } \\
\text { prevented from } \\
\text { using it }\end{array}$} & Difficult & $\begin{array}{l}\text { Public Goods } \\
\text { (Public provision) } \\
\text { free-to-air television, air, national } \\
\text { defence, scenic view, free } \\
\text { knowledge, } \\
\text { 1. emergency management for } \\
\text { zoonotic diseases, } \\
\text { 2. cooking recipes, } \\
\text { 3. gastronomy knowledge, } \\
\text { 4. safe food supply system, } \\
\text { 5. traditional agricultural } \\
\text { knowledge, } \\
\text { 6. genetic resources for food and } \\
\text { agriculture, } \\
\text { 7. regulation of extreme food } \\
\text { price fluctuations }\end{array}$ & $\begin{array}{l}\text { Common Pool Resources } \\
\text { (Natural provision) } \\
\text { timber, coal, oil fields } \\
\text { 1. ocean fish stocks, } \\
\text { 2. edible wild fruits and animals }\end{array}$ \\
\hline & Easy & $\begin{array}{l}\text { Club Goods } \\
\text { (Public or private provision) } \\
\text { cinemas, private parks, satellite } \\
\text { television, } \\
\text { 1. copyrighted agricultural } \\
\text { knowledge, } \\
\text { 2. hunting in game reserves, } \\
\text { 3. fishing and hunting licenses }\end{array}$ & $\begin{array}{l}\text { Private Goods } \\
\text { (Private provision) } \\
\text { clothing, cars, personal electronics } \\
\text { 1. cultivated food, } \\
\text { 2. privately owned agricultural land, } \\
\text { 3. Genetically Modified Organisms } \\
\text { 4. copyrighted improved seeds }\end{array}$ \\
\hline
\end{tabular}

Adapted from Hess \& Ostrom (2007)

Nevertheless, most goods do not exhibit these two characteristics in pure form and a significant number of global public goods are non-excludable or non-rival only to a degree (Hampson \& Hay, 2004). They have mixed features and are referred to as "impure or near-public goods". The impure goods can either be "club goods", excludable but non-rival (Buchanan, 1965) or "common-pool goods", rival but non-excludable. The private market incentive to provide public and near-public goods is weak, meaning they will only be supplied at sub-optimal levels from society's perspective. Hence, in the case of public and near-public goods the market fails and government shall intervene. Adam Smith already observed that some goods are regularly underprovided simply because profits cannot be recaptured by the suppliers of those goods. And when markets cannot provide such advantageous goods, governments should. 
Common pool goods apply well to wild edible plants and animals, and they suffer from depletion through over-use and free-riding (Sands, 2003). Club goods are those whose costs and benefits are shared among and limited to a specific group of individuals, the club, and they are funded through a blend of taxpayer subsidy and user fees. Hunting or fishing licenses or game reserves are food-related examples. Club goods can be either publicly or privately provided and often result in the creation of monopoly power. Sometimes club goods are provided by the public sector and funded either entirely through user fees or through a combination of user fees and taxpayer subsidization (e.g. public buses). Alternatively, private firms may provide the good or service with regulatory oversight to regulate the price as it has been the case of the price of staple food.

\section{7.- The enclosure of food: the privatization of a basic human need}

During the long-lasting hunting-gathering period of our human history, food and water were widely considered as commons goods. Nature was providing food in form of wild fruits, roots, leaves, animals, fishes, sea fruits or running water. Food was all over the planet, freely available to anyone with enough knowledge to hunt it, grab it or find it. Although food and water are intrinsically rivalrous (whatever you eat or sip goes to your stomach and prevents others to eat the same piece), their abundance and renewal was exceeding by far human needs. Wild animals and vegetables were commonly found across the globe (except some areas of the Poles), with no private ownership or control over them, and they were thus non-excludable. At that time, they would be considered global common goods. Later on, between twelve to ten thousand years ago, the domestication of some crops and animals provided surplus food that allowed the development of cities and the consolidation of primitive forms of property rights. People around the world exchanged food and biological materials, mainly for food and agricultural purposes (Morgan 1979; Diamond 1997), and agriculture and food trade grew quickly and extensively, reaching all regions.

The natural world is gradually but steadily being brought under private control with the aim of making profits, instead of supplying the needs of people. The privatization of what in the past was considered a public common good is supported by extensive new legislation, being praised and promoted by Transnational Companies. Enclosure is the gradual or sudden decrease of accessibility of a particular resource due to privatization, new legislation or overconsumption (Hess, 2008). Privatization and enclosure of natural resources meant the transfer of common properties "from the many to the few" (Nuijten, 2006). For example, fishing from the seashore or collecting mushrooms from the forest used to be free and now are regulated by license or banned in many areas and seasons. Nevertheless, evidence from Africa suggests that privatization schemes to control tribal rangelands have in fact worsen inequalities (REFERENCES).

The foundational premises of capitalism and its radical version we experience today (globalised neoliberalism) are the primacy of individual proprietary rights and the endless accumulation of profits (Scholte, 2005) and the food system has not escaped from that transformation. Private property is regarded as the fundamental right, with sovereign borders as the inalienable space and the enclosure of the commons as the long-term goal to be achieved by force, legal measures or market rules (Quilligan, 2012). However, the world is still rather diverse in proprietary schemes, and the private arrangements, highly dominant within the realm of the agro-industrial agriculture, are not equally prevalent in other areas of the world, where subsistence, traditional and agro-ecological types of agriculture are the norm. Actually, in numbers, the small traditional farmers that have mixed proprietary arrangements for natural resources are the great majority, with only 27 million farmers working with tractors, 250 million using animal traction and more than a 1 billion working just with their hands and tools. About 500 million sub-Saharan Africans still rely on communally held land (Kugelman \& Levenstein, 2013), and the same can be said of millions of Latin American people (REFERENCES).

Traditionally, capitalism tends to over-exploit natural resources to overcome economic crises, not fully incorporating the externalities causes by the production/consumption processes. The enclosure and full privatization of goods owned by no one explains an important aspect of capitalism's insatiable appetite (Arvanitakis, 2006). Resource grabbing, either food, water, soil or energy, is an expression of an 
economic model of development in which capital accumulation is linked to increasing control over abundant and cheap supplies of natural resources. Examples of this commons-public-private rebranding include water, food, forests, energy, health services, schools, culture, indigenous artifacts, parks, community zoning, knowledge, means of communication and ecological and genetic resources (Quilligan, 2012). As industrial methods were applied to raising crops and animals, the agricultureinput sector grew dramatically and became highly concentrated, with relatively few companies now producing and selling farm machinery, fertilizers, pesticides, and seeds. Market concentration in the past 20 years has been significant not only in food production, but also in food transportation and retailing, and in agrochemicals where seven companies accounted for $90 \%$ of worldwide sales in 2001 (Lang, 2003). A few transnational corporations are able to exert near monopoly power all along the industrial food chain, from the seeds to the ready-to-eat meals sold in the supermarkets. The agri-food corporations have stakes in land-grabbing initiatives, in water companies and the retailer sector as well. The top 10 multinational seed companies now control $73 \%$ of the world's commercial seed market, up from 37\% in 1995 (ETC Group, 2011). The innovation in agricultural research in the last 30 years has been greatly privatized, and put under control by license and patents (Benkler, 2006, p. 336). Copyrighted crops are relentlessly increasing with over 170 million hectares of GMO already cropped in 2012, a 6\% increased from previous year (10.3 million hectares) (James, 2012).

Expanding copyrights, issuing permits or taxing specific activities enable enclosure of previous commons. Among the different types of enclosure, two schemes are quite relevant for the three essential goods (food, water and air). Setting quotas may be a way to address the problem of openaccess resources such as in fisheries (Young, 2003), although setting appropriate quota levels requires governments to collect and analyse a lot of information and enforcing regulations, adding to the cost of this policy (Rocha, 2007). Another form of enclosure of the commons is developing new markets for the services these common-pool resources provide. The 1997 Kyoto Protocol was the first attempt to create an international market for permits for greenhouse gases, being also regarded as the first steps towards the enclosure of the pure air in the atmosphere. Forest environmental services also present a great array of enclosure cases, either the REDD+ or the bird- or forest-friendly coffee labels.

\section{8.- Why the market cannot guarantee food and nutrition security and the right to food for all?}

Food security incorporates the notion of accessibility to food that can be increased by providing enough income to all, but it goes beyond that to include food safety, quality, and diversity according to social/cultural norms. Additionally, food sovereignty also encompasses the environmental sustainability of food production and distribution systems, and the human dignity in producing and accessing food. Access to food will improve with more income allocated to the poor, but market failures do not disappear simply by turning people into consumers. Income security can increase food security, but it cannot eliminate all conditions leading to food insecurity.

One of the great illusions of recent decades has been that market forces by themselves could regulate the national and international food systems to pull hungry people out of the plight of starving and destitution. It was amply believed and praised that market-led food security would finally achieve a better nourished population, as long as the world's average wealth increases. Along those lines, food production and food access are mostly governed by market rules: you pay and your crop or you pay and you eat. The enclosure mechanisms, through privatization or legislation, have played a role in limiting the access to food as a public good.

However, reality has proven otherwise. Unregulated markets may still not provide a socially efficient quantity of food even if enough income was distributed to low-income groups (Rocha, 2007), and thus hunger arises from negative market externalities (pollution, public health problems, unregulated use of common-resources, etc). Six sources of inefficiency in capitalism are especially important with regard to food security: the underproduction of public goods; the underpricing of natural resources; negative externalities; the weak monitoring and enforcing of market contracts; the primacy of intellectual property rights; and the costs of inequality (Wright, 2010). Free markets, governed by private, individual self-interest, will not provide an adequate quantity of public goods with enormous although 
non-monetised benefits to human beings (Ver Eecke, 1999), as the beneficial externalities cannot be captured by those private markets. The market will under-provide public goods since the market mechanism works on the principle that those who cannot pay for a good cannot consume it. Traditionally, the solution for the absence of efficient markets for public goods has been to have these goods produced and delivered by governments, as benefiting the maximum amount of citizens and increasing their welfare is the primary goal of the government.

Box 3: The quest for scarce arable land as a collateral effect of excessive commodification

Land-grabbing schemes are catching media attention, with private capital and sovereign wealth funds purchasing or leasing land in Africa, Asia, and Latin America to produce food and biofuels for exporting to the investor's home country. Food-importing nations and profit-seeking private corporations are acquiring farmland overseas at unprecedented scale. Nearly 230 million hectares of farmland, an area equivalent to the size of Western Europe, have been sold or leased since 2001, with most of these transactions occurring since 2008 (Kugelman \& Levenstein, 2013). This land could feed a billion people, exceeding the number of people who go to bed hungry each night (Oxfam, 2012). They cultivate the land themselves to get staple food and biofuels, and export the harvests back home to feed their citizens or industries. More than 40 percent of the land involved in overseas farmland acquisitions is to set aside for biofuels production (Kugelman \& Levenstein, 2013). Some examples are Cambodia, where in 201155 percent of arable land has been acquired by domestic and foreign agribusiness interests. More than 30 per cent of the land in Liberia has been handed out in largescale concessions in the past five years, often with disastrous results for local people (Oxfam, 2012).

Despite the common reliance on industry self-regulation and public-private partnerships to improve public health and nutrition, there is no evidence to support their effectiveness or safety (Moodie et al., 2013). Transnational corporations are major drivers of non-communicable disease epidemics and profit from increased consumption of tobacco, alcohol, and ultra-processed food and drink, the socalled unhealthy commodities. So far, the only evidence-based mechanisms that can prevent harm caused by unhealthy commodity industries are public regulation and market intervention. In plain terms, more state not less.

There are several implications of treating food as a mere commodity:

1. Food crops have many different uses other than direct human consumption, such as feed for livestock, biofuel, pharmaceutical by-products or industrial raw materials. The best use of any commodity is where it can get the best price.

2. Another implication of the commoditised nature of food is the unethical speculation with staple food. The amount of money in natural resources-based funds increased from $\$ 13$ billion in 2003 to $\$ 317$ billion in 2008 (Magdoff, 2012).

3. We are witnessing an out-of-control race for scarce natural resources since 2008, with landgrabbing, water-grabbing, Arctic and Antarctic preliminary exploitation schemes and shalegas fracking as just examples with global implications. The chief drivers of the this new colonialism are population growth, food and energy demand, volatile and high commodity prices, dietary transition to meat-dominated meals and land and water shortages, with any of those expected to slow anytime soon. By 2015, more than 200 private equity firms are expected to have almost $\$ 30$ billion invested in overseas land grabbing schemes (Kugelman \& Levenstein, 2013).

4. Because food products are commodities and the only goal of the food and agriculture system is to sell more and make more profits, the other dimensions of food presented above (the fundamental right to be free from hunger, the cultural implications of cropping and cooking or the public health benefits of a good nutrition) are overshadowed by the profit goal. That is why the world still harbours 868 million undernourished people and more than 500 million obese and the meat-based transition that is so resource-demanding is dominating world diets.

5. Finally, a food system anchored in the consideration of food as a commodity to be distributed according to the demand-offer market rules will never achieve food security for all, and least to say the aspirational status where every human being can have his/her right to food guaranteed. It is evident that the private sector is not interested in people who do not have the money to pay for their services or goods, either be videogames or staple food. 


\section{9.- Food as a commons}

Public goods that are available everywhere are sometimes referred to as global public goods. Nevertheless, food and water are available everywhere and yet not considered public goods. Food is found all over the world, except the Poles, either produced by nature or human-made, and it benefits everybody. Food is central to life and none can fully control all food produced by Earth. Moreover, in a global world, food security is beyond the control of any institution or state.

Food is public in consumption and a mixed good in production, as it can be privately produced, state produced and naturally produced. Food is a de facto mixed good, governed by public institutions in many aspects (food safety regulations, seed markets, fertilizer subsidies, the EU Common Agricultural Policy and US Farm Bill provisions), provided by collective actions in thousands of customary and post-industrial collective arrangements (cooking recipes, farmers' seed exchanges, consumerproducers associations) but largely distributed by market rules: you eat as long as you have money to purchase either food or food-producing inputs. However, man-made food is an impure public good, as food is rival but not ontologically excludable as every human has to eat every day, three times ideally, to keep on living.

Very recently, the status of food security has been regarded as a global public good by the Committee of World Food Security based at FAO in Rome (De Schutter in press) although this consideration had already been mentioned by some commoners (Quilligan, 2012) and food sovereignty proponents (Rosset, 2006). The global food price crisis of 2008 was a major turning point in this regard, and food and nutrition security is nowadays a major political concern for any global institution (WEF, 2013; G20, G-8, WTO REFERENCES).

There is a need to reverse the process to excessive commodification of food, understood this as the trend to develop the traits and goods that fit better with the mechanized processes and standardized regulations put in practice by the agri-business and the governments (Manno, 2002). And we need to reclaim a narrative of the commons to reassess the excessive commodification of some resources and the re-commonification of others (Bollier, 2002).

What triggers the re-conceptualization of food as a commons? Using Hess' entrypoints: the need to protect this essential resource from excessive commodification and control by a few, the desire to build civic education towards this resource and the evolving nature of some food-related elements that are already considered as global commons (Hess, 2008). The de-commodification implies to delink commodities and well-being, rising the proportion of goods and services consumed outside the regulated formal market, either acquired in the public sphere (public services) or in the autonomous sphere (fair trade, exchange groups, producers-consumers associations, community-supported agriculture, etc).

\section{0.- De-constructing food-related elements: all dimensions are considered as commons except the cultivated food.}

Recent documents and public statements indicate that policy makers are moving from the technical definition of a pure public good elaborated by the economic theorists to a looser but more inclusive definition of the so-called impure public goods (Gerrard et al., 2012, p. 3), those goods that many economists already call "merit or social goods" who are those that different members or groups in society believe that the state or other publicly interested entities or groups should provide to society as a whole (Hampson \& Hay, 2004).

The ancient commodification of food and the modern trend for water nowadays are human-induced processes that deal more with the private property of natural resources than with the intrinsic nature of the good. Publicness and privateness are not innate properties of a good, but the result of social or political choice. Therefore, it is important to distinguish between the potential and de facto publicness of a good (Kaul, 2013). Features of food as a private good are merely social constructs that can be de- 
constructed and re-constructed in a different way provided there is a common agreement within our societies. The commodification process can be reversed and a re-commonification of food and water is deemed an essential paradigm shift in light of the global fight against hunger and malnutrition. However, there is still a long road to go, as even those authors or institutions that are really committed to hunger eradication usually consider that free markets improve food production and access (REFERENCES NEEDED).

In this section, we are to deconstruct the food concept and to prove that most of its dimensions are considered, to a certain extent, common goods or even global common goods; while others are contested (naturally produced food and water) or generally regarded as private goods (cultivated food and livestock). The term "food" embraces the following dimensions:

\section{a.- Cultivated food (crops and livestock):}

Limited but renewable resources essential to human life and broadly considered as private goods, largely produced in private or state-owned lands with private and public goods (seeds, fertilizer, rainfall, irrigation, machinery, human labour force).

\section{b.- Traditional agricultural knowledge accumulated after thousands of years of practices:}

For centuries, small farmers, peasants and indigenous people have developed agricultural innovations that produce food in harmony with the surrounding environment, preserving seeds, land, water and community social life. The modern world needs to rediscover these commons-based solutions, generally regarded as common goods (knowledge perfectly qualifies as a global and pure public good). Commons-based patent-free agricultural innovations would greatly contribute to global food security by upscaling and networking grassroots innovations for sustainable and low cost food production and distribution. The governance of this networking shall be adaptive and based on polycentric nodes and unpatented shared knowledge.

\section{c.- Modern science-based agricultural knowledge produced by national institutions:}

Most of the agricultural science and knowledge generated by private companies is finally copyrighted, but the knowledge produced by national institutions (universities and research centres) is public. Foodrelated scientific knowledge produced by state-owned institutions should be used for the common good, and not just for the benefit of large agribusinesses. In that sense, more research funds shall be invested in sustainable practices and agro-ecology, not further subsidizing industrial agriculture.

\section{d.- Cuisine, recipes and national gastronomy}

Food, cooking and eating habits are inherently part of our culture, and it determines who we are in the world, inasmuch as language and birthplace. Moreover, cooking is also regarded as a creative accomplishment of humankind, equalling literature, music or architecture. Recipes are commonly exchanged within family networks, friends and even unknown interlocutors in almost every culture, what it is clearly a superb example of commons in action (Walljasper, 2011). Super-star cooks are not reluctant in sharing their recipes and gastronomy knowledge. Cooking knowledge is not patented, copyrighted or trademarked, although some traditional food-processing knowledge has already been copyrighted by market demands (AOC, Appellations of Origin). Surprisingly as it may be, in this copyright-free domain of human activity, creativity and innovation are still dominant, as it seems that the freedom to copy actually promotes creativity rather than deter it (Raustiala \& Sprigman, 2012).

\section{e.- Edible plants and animals produced by nature (fish stocks and wild fruits and animals)}

In economic terms, the environment is largely a public good so the natural resources produced by the environment shall also be public goods. Fish stocks, especially those in international waters, are generally accepted as common goods or common-pool resources in economic vocabulary (Christy \& Scott, 1965). But within this group we can also include terrestrial animal and plants, such as wild fruits and animals either if they are found in state-, commonly- or privately-owned lands. Depending on the proprietary rights schemes applied in each country, the wild biodiversity living in my own land may or may not be mine. 


\section{f.- Genetic resources for food and agriculture}

Genetic resources are generally accepted common goods, global in some cases (i.e. the International Treaty on Plant Genetic Resources for Food and Agriculture) and under sovereign state's control in many others. Seed exchange schemes are considered networked-knowledge goods with non-exclusive access and use conditions, produced and consumed by communities (Hess \& Ostrom, 2007). At present, there is a lively debate between defenders of free-patent seeds distribution and the industrial copyright system that benefits transnational agricultural companies. Agro-biodiversity is a whole continuum of wild to domesticated diversity that is important to people's livelihood, and it should be mostly patent-free to promote and enable innovation. There is an urgent need to find a balanced legal framework around the protection and use of agro-biodiversity in traditional farming systems, with emphasis on the cultural commons that genetic resources represent.

\section{g.- Food Safety considerations (Codex Alimentarius)}

Food safety is addressed as a global public good (Unnevehr, 2006) through a try-centric system of private sector self-regulating efforts, governmental legal frameworks working at national level (national food safety and consumer laws) and international institutional innovations such as the Codex Alimentarius, hosted by FAO in Rome, or the SPS agreement issued by the WTO. Epidemic disease knowledge and control mechanisms are amply considered as global public goods, as zoonotic pandemias are a public bads with no borders and thus its control is in everybody's interest.

\section{h.- Nutrition, including hunger and obesity unbalances}

There is a growing consensus that health shall be considered as a public good, either nationally or internationally (Anomaly, 2011; Chen et al., 1999; The Economist, 2009; WHO, 2002). And as good nutrition is an integral part of health, good nutrition for all should also be considered as global public good. Their nemesis however, hunger and obesity, shall be seen as public bads.

\section{i.- Extreme food price fluctuations in global and national markets}

Extreme financial instability is a public bad, and therefore economic stability is a public good (Wolf, 2012). Those acting inside the market system have no incentive to supply the good or avoid the bad, so there is a need of concerted action where the states have an important role to play. The very same argument can be used to value extreme food price fluctuations in global and national markets as a public bad that benefits none but a few traders and brokers. And since 2008 we have already experienced three important food peaks with accompanying high fluctuations.

\section{1.- What if food is considered a commons... The commons-based transition to sustainable agriculture}

This first approach to food as a commons seeks to contribute to the debate on the moral values that motivate people to produce, sell and consume food and the most appropriate institutional arrangements for achieving a sustainable food production for all. This paper aims at provoking further thoughts and reflexive knowledge, ideally produced in a commons-manner. The efforts to address the imbalances of the current industrialized food system are a classic collective action problem that we think is best addressed at multiple scales and levels.

If food is considered a commons or impure public good instead of a pure private good as considered by the dominant post-industrial food system, the legal, economic and political implications would be huge, although nowadays we can barely glimpse a few of them, the most straightforward. In the next sections, we merely sketch a tri-centric approach that could be helpful in steering the transition towards a sustainable food system. That justifies why we do not present detailed proposals on how this concept could be materialised in practice or why many gaps are still waiting to be enlightened by subsequent research in economic, philosophical, agricultural, legal and social areas. In any case, quoting Marx, detailed blueprints of alternative designs are often pointless exercises in fantasy.

On the other side, should hunger be considered a public bad, it would entail implications far beyond the hungry themselves and the countries harbouring hungry people, as eradicating hunger would be 
then considered a global duty, and the governance of the global food system should be reviewed accordingly. To date, advocating for anti-hunger measures has been very much depending on demonstrating the economic and political losses that hunger infringe to human societies and economics (World Bank, 2006, Grantham-McGregor et al. 2007; Martinez \& Fernandez, 2008). Hunger deters innovation and productivity, and therefore it brings huge economic losses. Hunger also triggers social unrest and political turmoil (Messner \& Cohen, 2008; Lagi et al. 2011; Holt-Giménez \& Patel, 2009). Alternative non-economic arguments and strategies to fight hunger have been largely neglected: ethical imperative (Pinstrup-Andersen, 2007), public health considerations (Sidel, 1997), social cohesion (FAO-CEPAL-PMA, 2007) or human rights approaches. Considering food as a commons will provide the adequate rationale to support these non-economic arguments.

The consideration of food as a commons could provide the background to reverse main threats to food and nutrition security, such as:

- Excessive commodification of food, with high-pricing, laws and private enclosure as main barriers to fully enjoy those vital resources

- Irregular private land titling, land grabbing and land evictions, as the proprietary right schemes would incorporate collective rights at national and international levels

- Excessive patents of life, bio-piracy and copyrighted GMOs, applying to agricultural and food innovations the same principles of the GNU free software (Stallman, 2012). See below for the four freedoms. The farmers and researchers would have the freedom to sow, distribute, study, select, modify and improve the seeds and its genetic material for its own benefit. Benkler (2006) clearly states that the copyrighted agricultural sector is deterring further innovation, an innovation very much needed if we want to increase our food production by $60 \%$ by 2050 (OECD-FAO, 2012).

- The concentration of agri-food chains in few transnationals.

- Discourage the enclosing schemes targeting the atmosphere, such as the Carbon Sequestration Initiative, the REDD+ and the Payment for Environmental Services.

\begin{tabular}{|l|l|}
\hline \multicolumn{1}{|c|}{ Freedoms of the GNU free software } & \multicolumn{1}{|c|}{ Freedoms of patent-free seeds } \\
\hline $\begin{array}{l}\text { The freedom to run the program, for any purpose } \\
\text { (freedom 0). }\end{array}$ & Freedom to use the seeds, for any purpose \\
\hline $\begin{array}{l}\text { The freedom to study how the program works, and } \\
\text { change it so it does your computing as you wish } \\
\text { (freedom 1). Access to the source code is a } \\
\text { precondition for this. }\end{array}$ & $\begin{array}{l}\text { Freedom to study how the seed works and how the } \\
\text { genetic information is translated into phenotypic } \\
\text { features. And the freedom to change that genetic } \\
\text { information as you wish (though due considerations } \\
\text { shall be given to ethical concerns in this case, as we } \\
\text { are dealing with living entities). }\end{array}$ \\
\hline $\begin{array}{l}\text { The freedom to redistribute copies so you can help } \\
\text { your neighbour (freedom 2). }\end{array}$ & $\begin{array}{l}\text { The freedom to redistribute seeds so you can help } \\
\text { your neighbour. }\end{array}$ \\
\hline $\begin{array}{l}\text { The freedom to distribute copies of your modified } \\
\text { versions to others (freedom 3). By doing this you can } \\
\text { give the whole community a chance to benefit from } \\
\text { your changes. Access to the source code is a } \\
\text { precondition for this. }\end{array}$ & $\begin{array}{l}\text { The freedom to distribute seeds of your improved } \\
\text { landraces to others (freedom 3). By doing this you can } \\
\text { give the whole community a chance to benefit from } \\
\text { your changes. Access to the genetic material is a } \\
\text { precondition for this. }\end{array}$ \\
\hline
\end{tabular}

Stallman, 2012.

\section{2.- Legal considerations of food as a commons}

Several authors have expressed the post-2015 agenda for development needs to contain an articulation of the various sets of global public goods, how they are financed, and which global institutions can be held accountable for the provision of these global public goods (von der Hoeven, 2012). In that sense, considering food as a public good as well as a human right could pave the way for more binding legal frameworks to fight hunger and guarantee the right to food for everybody, as well as reinforced 
cosmopolitan global policies (Held, 2009) and more fraternal ethics and legal frameworks (Gonthier, 2000) for the whole human race.

Another implication would be that food should be kept out from trade agreements dealing with pure private goods (Rosset, 2006). Food issues would be dealt with outside the WTO negotiations and there would be a need to establish a particular governing system for production, distribution and access to food. Moreover, there would be a legal and ethical ground to ban on futures trading in agricultural commodities, as the futures trading activity influences considerably the international and domestic prices (Jian et al., 2005). Subsequently, there would a need to develop an international legal framework to regulate food at global level, complementing the national legislations and the international agreements currently in use (ICESCR, Deep Sea Oceans, Antarctica...). A binding Food Treaty (MacMillan \& Vivero, 2011) could be an example of global legal agreement to guarantee the common dimension of food as an essential element to human beings survival and as a human right. Binding agreements as legal tools to materialise global governance of the commons have also being proposed for other commons such as climate change (Griggs et al., 2013) and universal health coverage (Gostin et al., 2011). The political and legal framework that governs food as a global public good could take shape as, for example, a global union where sovereign countries should share part of its sovereignty regarding food to that international institution (Corner, 2008; McClintock, 2010). But these immediate considerations on legally-binding food agreements are not expected to become real without a strong opposition from the market power and lobbying pressures of companies that dominate food systems in the global market.

Another legally-based scheme anchored in the consideration of food as a commons could be a universal Basic Food Entitlement, whereby the State shall guarantee a minimum amount of food for all, a social guarantee scheme similar to the basic income for all (Van Parijs, 2005) or the Social Protection Floor (Deacon, 2012). Just recently, the term "food security floor" has been coined whereby a minimum set of policies are put into practice to protect the only human right declared as a fundamental right in the ICESCR: freedom from hunger (HLPE, 2012). These type of state-regulated measures could be implemented during the transition period, as a sort of Food Floor to get rid of hunger quickly and similar to the called Economic Transition Income proposed by Arnsperger \& Johnson (2012). State institutions could govern, guarantee and provide a minimum amount of food for everyone, either in kind or in cash. During the transition period, and as an immediate mechanism, the state should guarantee a minimum amount of income to purchase enough food: the minimum salary shall be equal to the food basket in all countries.

Innovation in agricultural and nutrition research and evidence-based locally-adapted technologies would highly benefit from this consideration of food as a commons, fostering crowdsourcing innovations and creative-commons licensing systems to improve the sustainability and fairness of the global food system. Proprietary rights by private companies of food related elements, such as seeds, processed foods or agricultural knowledge, prevent further innovation by the stakeholders involved (either farmers or consumers), and thus copyrighted schemes deter rather than trigger broad agricultural innovations. Millions of people innovating have far more capacity to find adaptive and appropriate solutions that a few thousands of scientists in the laboratories and research centres (Benkler, 2006). Along those lines, Benkler presents how a creative commons approach to food security and agriculture can stimulate progress in hunger eradication and sustainable food systems, although his examples are confined to science-based networks such as PIPRA (Public Intellectual Property for Agriculture), a network of public US universities, or BIOS (Biological Innovation for an Open Society), an initiative by the australian NGO Cambia on open source biotech agricultural developments. 


\section{3.- The tri-centric governance of the local food systems: markets, governments and civic collective actions for food}

There is an urgent need to rearrange the food system governance, devolving control power from the state to the commons, and rebranding privately-owned food stuff and food-producing resources. Nowadays, in different parts of the world, there are many initiatives that demonstrate that a right combination of collective action, governmental rules and incentives, and private sector entrepreneurship yield good results for food producers, consumers, the environment and society in general, and the challenge now is how to scale up those local initiatives to national level. The commons are gaining ground as a third force of governance and resource management by the people as a compliment to the market and the state. Unlike the market, the commons are about cooperation, stewardship, equity, sustainability, and direct democracy from local to global.

Paralleling the polycentric approach to climate change proposed by Ostrom (2009), single policies adopted only at a global scale (i.e. the Updated Comprehensive Framework for Action of the High Level Task Force on the Global Food Security Crisis or the Millennium Development Goals) are unlikely to generate sufficient trust among citizens and firms so that collective action can take place in a comprehensive and transparent manner to reduce hunger and tackling global food security (production and consumption). The solution to the unsustainability of the food system and their negative effects on malnutrition will not arrive in a blueprint agreement or a silver-bullet panacea (Ostrom, 2012), but will require experimentation at multiple levels (personal, local, national, international) and diverse approaches to governance (market-led, state-led and collective action-led).

The foundations of many civic collective actions for food lay on the multiple consideration of (a) food as basic human need that shall be available to all, (b) food as fundamental human right that shall be guaranteed to every citizen, (c) food as a pillar and major feature of our culture either as producers of consumers of food, (d) food as a marketable product subject to fair trade and sustainable production and (e) food as a global common good that shall be enjoyed by mankind. In that sense, food considered as a tradable commodity only reveals one fraction of the whole meaning, being in any case just a means to facilitate access to all, and not to determine who can get access to that food. In that sense, customary and post-industrial food civic actions share a consideration of food as a commons that radically diverges from the mainstream industrial food system that merely considers food as a commodity.

The re-commonification of food shall take several generations so the transition phase should witness the coexistence of a dual consideration of food: as a common good, whereby a minimum amount of food should be available and accessible to every human being; and as a private good still tradable and subject to excludability and rivalry. Market rules have proven unsuccessful in reaching a sustainable production and fair distribution of food to every human being, although enough food is available to feed us all adequately. Therefore, governmental regulations and collective actions are also essential to ensure a fair distribution of this essential good, so as to satisfy the caloric needs and cultural preferences of humans. The transition path can be compounded of soft changes or disruptive changes, but it will likely be a heterogeneous mix of both (Quilligan, 2012). Although at the initial stage of the transition period the State should take a leading role in guaranteeing food for all, that leading role should gradually be shifted to the self-negotiated collection actions by groups of producers and consumers, as the State provision of food does not surpass the net benefit that consumers would receive through the self-organized and socially negotiated protection, production and use of their own resources.

The tri-centric governance schemes shall be compounded of (a) civic collective actions for food undertaken initially at local level and whose aim is mostly preserving and regenerating the commons that are important for the community (food as a common good); (b) governments whose main goal is to maximize the well-being of their citizens and providing an enabling framework to enjoy the commons (food as a public good); and (c) the private sector that can prosper from the surplus 
resources it owns or rents from the owners of the commons, either the community or the state (food as a private good).

\section{3.a.- Civic Collective Actions for Food or Alternative Food Networks: Innovative self-governing communities as key units for the transition}

Commons-based principles and models have the potential to build a rich array of stable, equitable and ecological alternatives to conventional food markets while strengthening communities and networks. The local institutional arrangements that generate and govern local food systems (production and consumption) are essential bricks of any reconfiguration of the global food system to render it more sustainable and productive enough to feed all of us by 2050 and beyond. People's capacity for collective action is an agency that can complement the regulatory mandate of the state and the demand-driven allocation by the private sector. Ostrom (1990) and her polycentric approach to governing the commons helped us understand how institutional diversity is the most suitable and successful solution to maximize the material and non-material outputs of common goods.

A possible transition path from the current scenario to the commons-based one would be testing and scaling up approaches in small- to medium-scale governance units that are linked together through information networks (Dedeurwaerdere, 2005) and monitoring at all levels, including accountability, transparency and participation (De Schutter \& Cordes, 2011). Food could be produced, consumed and distributed by hybrid institutional arrangements formed by state institutions, private producers and companies, and self-organized groups under self-negotiated rules, such as those actions labelled as Community-Supported Agriculture in the US (Abbott-Cone \& Myhre, 2000). Those self-organized groups or communities of users and the local rules they develop are key components of the emergent polycentric governance of natural resources described by Ostrom (2005).

A community can be understood as group of people with a shared interest in the sustainable use of a given resource, implying communication and commitment between people who can interact to arrive to governance rules concerning the resource. Local communities willing to govern their own resources may formalize this through a social charter and food trusts, associations or non-governmental organizations. An example for a Food-related Charter was already proposed by Maxwell (1997) to mobilise political commitment at local and national level to reach food security and fight against hunger, and the institutional shape of collective actions may be materialised as cooperatives, self-help groups or social enterprises. Many food communities have developed their own sets of norms and rules to oversee their collective food resources sustainably, both for themselves and for future generations. The decentralized, self-governing systems of food production also offer fairer access to resources and higher efficiency than can be gained through distributive enterprises operated as private monopolies or state hierarchies (Quilligan, 2012).

Recently-proposed Food Trusts, as catalysts for the integration of producers and consumers, could be a nice example of this tri-centric governance arrangement (The Food Commons, 2011; Nature et Progrès, 2012). Food Trusts could own farm land and water resources, produce food, lend money to low-carbon groups and guarantee food for every citizen through a basic food entitlement. Trusts are generally created to preserve depletable resources, but many replenishable commons can also benefit from trusts that ensure their regeneration (Quilligan, 2012). Trustees set a cap on the extraction or the use of a resource according to non-monetized, intergenerational metrics such as sustainability, quality of life and well-being. Having protected a commons safely for future generations, the trust may rent a proportion of the resources beyond the cap to the private sector or to state businesses and utilities for extraction and production. A percentage of this rent is taxed by the state and redistributed to citizens as dividends or subsistence income, with emphasis on the poor and marginalized.

\section{3.b.- Governmental rules}

Food provision and food security shall involve greater levels of public sector involvement due to the market failure. There are many dimensions of food that are already considered as public goods and 
they should be governed by the government. This suggests the need for the public sector funding schemes to guarantee a minimum food for all. The state must be seen not only as a regulatory mechanism for diverse and sometimes conflictive interests, but also as an funding and operational instrument for the achievement of socially desired collective goods and the well-being of all of society's members, being the food security of the population clearly one of those.

As recent examples of governmental rules that may contribute to facilitate the transition towards sustainable food systems, two taxing proposals are quite relevant: taxing meat to incentivise a reduction in consumption as suggested in a recent report by the Swedish Board of Agriculture (2013) or taxing fast food with high contents of sugar, fat and salt (De Schutter, 2011). Both proposals will surely become a reality within a decade, as part of government schemes to supervise the uncontrolled rise meat production and consumption due to the environmental, social and health consequences.

13.c.- For-profit food companies and social entrepreneurship (TO BE DEVELOPED NEXT) 


\section{Bibliography}

Abbott Cone, C. \& A. Myhre (2000). Community-Supported Agriculture: A Sustainable Alternative to Industrial Agriculture? Human Organization Vol. 59, 2: 187-197

ACF-MSF (2009). One crisis may hide another: food price crisis masked deadly child malnutrition. Briefing paper. Action Contre la Faim International Network and Médecins Sans Frontieres.

Alpen Capital (2011). The Gulf Countries Consortium. Page 5.

http://www.alpencapital.com/downloads/GCC Food Industry Report June 2011.pdf

Anomaly, J. (2011). Public Health and Public Goods. Public Health Ethics (2011) 4 (3): 251-259. doi: 10.1093/phe/phr027

Arnsperger, Ch. \& W.A. Johnson. (2012). The guaranteed income as an equal-opportunity tool in the transition toward sustainability. in A. Gosseries \& Y. Vanderborght (eds.), Arguing about justice. Essays for Philippe Van Parijs. Presses universitaires de Louvain, Louvain-laNeuve.

Arvanitakis, J. (2006). The Commons: Opening and Enclosing Non-commodified Space. Portal Journal of Multidisciplinary International Studies. Vol 3, No 1.

Benkler, Y. (2006). The wealth of networks. How social production transforms markets and freedom. Yale University Press. New Haven. Pp 329-344

Barlow, M. (2007). Blue Covenant: The Global Water Crisis and the Coming Battle for the Right to water. The New press, New York.

Bengoa, J.M. (2001). Food transitions in the 20th-21st century. Public Health Nutrition 4 (6A): $1425-7$.

Blanchflower, D.G., A.J. Oswald \& S. Stewart-Brown (2012). Is Psychological Well-being Linked to the Consumption of Fruit and Vegetables? National Bureau of Economic Research Working Paper No. 18469. Issued in October 2012. http://www.nber.org/papers/w18469

Bollier, D. (2003). Silent theft. The private plunder of our common wealth. Routledge, New York.

Brousseau, E., T. Dedeurwaerdere \& B. Siebenhuner (2012). Reflexive governance for global public goods. The MIT press, Boston.

Buchanan, J. (1965) An economic theory of clubs. Economica, 32, pp. 1-14.

Caraher, M. \& J. Coveney (2004). Public health nutrition and food policy. Public Health Nutrition, 7(5), 591 - 598.

Carpenter, P.A. \& P.C. Bishop (2009). The seventh mass extinction: Human-caused events contribute to a fatal consequence. Futures, vol. 41, Issue 10, December 2009, Pages 715-722. doi: 10.1016/j.futures.2009.07.008

Chen JD \& H. Xu (1996). Historical development of Chinese dietary patterns and nutrition from the ancient to the modern society. World Rev Nutr Diet. 79:133-53.

Chen, L.C., T.G. Evans \& R.A. Cash (1999). Health as a global public good. In Inge Kaul, Isabelle Grunberg \& Marc A. Stern, eds. Global public goods. International cooperation in the 21st century.

UNDP, Oxford University Press.

Christy, F. T. \& A. Scott (1965). The common wealth in ocean fisheries; some problems of growth and economic allocation. Johns Hopkins Press, Baltimore.

Clapp, J. \& D. Fuchs, eds. (2009). Corporate power in global agrifood governance. MIT press, Cambridge, MA.

Corner, M. (2008). Towards a Global Sharing of Sovereignty. European Essay No. 44. The Federal Trust. London. http://www.fedtrust.co.uk/content.php?cat id=4\&content id=123

Datamonitor. http://www.datamonitor.com/Default.aspx

Deacon, B. (2012). The social protection floor. CROP Poverty Brief http://www.crop.org/viewfile.aspx?id=415

De Onis, M et al. (2011). Prevalence of stunting among pre-school children 1990-2020. Public Health Nutrition, Jul 14:1-7

De Schutter, O. (2011). The right to an adequate diet: the agriculture-food-health nexus. Report presented at the 19th Session of the United Nations Human Rights Council. A/HRC/19/59.

De Schutter, O. \& K.Y. Cordes, eds. (2011). Accounting for Hunger. The Right to Food in the era of Globalisation. Hart Publishing, Oxford. Deacon, B. (2012). The social protection floor. CROP Poverty Brief, October 2012. http://www.crop.org/viewfile.aspx?id=415

Dedeurwaerdere, T. (2005). The contribution of network Governance to Sustainable Development”, Les séminaires de I'IDDRI, n¹3. http://www.iddri.org/Evenements/Seminaires-reguliers/s13 dedeurwaerdere.pdf 
Diamond, J. (1997). Guns, germs and steel. A short history of everybody for the last 13,000 years. Vintage, London. Pp. $85-156$ Digital Library of the Commons http://dlc.dlib.indiana.edu/dlc/handle/10535/830

Ecologistas en Accion (2012). La calidad del aire en el Estado Español durante el 2011. http://www.ecologistasenaccion.org/IMG/pdf/informe calidad aire 2011.pdf

ETC Group (2009). Who Will Feed Us? Questions for the Food and Climate Crises. ETC Communique no. 102, Ottawa. http://www.etcgroup.org/en/node/4921

ETC Group (2011). Who Will Control the Green Economy? Corporate Concentration in the Life Industries. Communiqué 107. ETC Group, Ottawa.

Euromonitor. http://www.euromonitor.com/

FAO (2011). Global food losses and food waste. Extent, causes and prevention. FAO, Rome \& Swedish Institute of Food and Biotechnology, Gothenburg. http://www.fao.org/docrep/014/mb060e/mb060e00.pdf

FAO (2012). The future we want. End hunger and make the transition to sustainable agricultural and food systems. FAO, Rome.

FAO, CEPAL \& PMA (2007). Hambre y Cohesión Social. Cómo revertir la relación entre inequidad y desnutrición en América Latina y el Caribe. FAO Santiago, Chile. http://www.rlc.fao.org/iniciativa/librocs.htm

FAO, WFP \& IFAD (2012). The state of food insecurity in the world. Economic growth is necessary but not sufficient to accelerate reduction of hunger and malnutrition. FAO, Rome.

Fernandez-Armesto, F. (2002). Near a thousand tables. A history of food. Free Press, New York.

Fogel, R.W. (2004). The escape from hunger and premature death, 1700-2100. Europe, America and the Third World. Cambridge University Press, New York.

Forbes (2007). The world's biggest industry. Forbes, 15 November 2007.

http://www.forbes.com/2007/11/11/growth-agriculture-business-forbeslife-food07-cx_sm_1113bigfood.html

Fraser, E.D.G. \& A. Rimas (2011). Empires of food. Feast, famine and the rise and fall of civilizations. Arrow Books.

Gerrard, C.L., L.G. Smith, B. Pearce, S. Padel, R. Hitchings, M.measures \& N. Cooper (2012). Public goods and farming. In Lichtfouse, E. (ed.), Farming for food and water security. Sustainable Agriculture Reviews 10. Springer, Dordrecht. DOI 10.1007/978-94-007-4500-1_1

Gonthier, C.D. (2000). Liberty, Equality, Fraternity: The Forgotten Leg of the Trilogy. Mcgill Law Journal / Revue de Droit de Mcgill, vol. 45: pp. 567-589. http://cisdl.org/gonthier/public/pdfs/publications/Liberty Equality Fraternity - Charles D Gonthier.pdf

Goodstein, E. S. (1995). Economics and the Environment. Englewood Cliffs, Prentice-Hall.

Gostin L.O. et al. (2011). The Joint Action and Learning Initiative: Towards a Global Agreement on National and Global Responsibilities for Health. PLoS Med 8(5): e1001031. doi:10.1371/journal.pmed.1001031

Gorenflo, L.J. et al. (2012). Co-occurrence of liguistic and biological diversity in biodiversity hotspots and high biodiversity wilderness areas. Proc. Nat. A. Sci. http://www.pnas.org/content/early/2012/05/03/1117511109.short

Grantham-McGregor, S. et al (2007). Development potential in the first 5 years for children in developing countries. The Lancet, 369:60-70

Griggs, D., M Stafford-Smith, O. Gaffney, J. Rockström, M.C. Öhman, P. Shyamsundar, W. Steffen, G. Glaser, N. Kanie \& I. Noble (2013). Sustainable development goals for people and planet. Nature, vol 495, 21 March: 305-307.

Gross, R \& P Webb (2006). Wasting time for wasted children: severe child undernutrition must be resolved in non-emergency settings. The Lancet, 367: 1209-1211.

Haddad, L. (2003). Redirecting the Diet Transition: What Can Food Policy Do?. Development Policy Review, 21 (5-6): 599-614.

Hampson, F.O. \& J.B. Hay (2004). Review Essay: Viva Vox Populi quick view. Global Governance, Vol. 10, No. 2 (Apr.-June 2004), pp. 247264

Hardin, G. (1968). The Tragedy of the Commons. Science 168, December 13.

Heinberg, R. \& M. Bomford (2009).The Food and Farming Transition: Toward a post-carbon food system. The Post Carbon Institute, California, USA

Held, D. (2009). Restructuring global governance: cosmopolitanism, democracy and the Global Order. Millenium: Journal of International Studies. Vol 37, No 3, pp. 535-547. 
Hess, C. (2008). Mapping the New Commons. Presented at "Governing Shared Resources: Connecting Local Experience to Global Challenges;" the 12th Biennial Conference of the International Association for the Study of the Commons, University of Gloucestershire, Cheltenham, England, July 14-18, 2008.

Hess, C. \& E. Ostrom, eds. (2007). Understanding Knowledge as a Commons: From Theory to Practice. MIT Press, Cambridge, MA.

HLPE (2012). Social protection for food security. A report by the High Level Panel of Experts on Food Security and Nutrition of the Committee on World Food Security, Rome 2012. 58-59.

http://www.fao.org/fileadmin/user_upload/hlpe/hlpe documents/HLPE Reports/HLPE-Report-4-Social_protection for food securityJune 2012.pdf

Hobbes, T. (1651). Leviathan. Oxford University Press, 1996

Holt-Giménez, E \& R Patel (2009). Food Rebellions: Crisis and the Hunger for Justice. Fahumu Books, UK

IAASTD (2009). Agriculture at a crossroads: the global report. Island Press.

IMAP (2011). Food and beverage industry global report 2010. IMAP Consumers staple report. http://www.imap.com/imap/media/resources/IMAP Food Beverage Report WEB AD6498A02CAF4.pdf

James, C. (2012). Global Status of Commercialized Biotech/GM Crops: 2012. ISAAA Brief No. 44. International Service for the Acquisition of Agri-biotech Applications: Ithaca, NY.

Jian, Y., BR Balyeat \& DJ Leatham (2005). Futures trading activity and commodity cash price volatility. Journal of Business finance and accounting 32: 297-323.

Kaul, I. (2013). Global Public Goods A concept for framing the Post-2015 Agenda? German Developmemnt Institute Discussion paper 2/2013, Bonn. http://www.die-gdi.de/CMS-Homepage/openwebcms3 e.nsf/\%28ynDK contentByKey\%29/ANES-959D4N/\$FILE/DP\%202.2013.pdf

Kaul, I., P. Conceição, K. Le Goulven \& R.U. Mendoza (eds.) (2003). Providing Global Public Goods: Managing Globalization. Oxford University Press, New York. DOI: 10.1093/0195157400.001.0001

Kaul, I. \& R.U. Mendoza (2003). Advancing the concept of public goods. In Inge Kaul; Pedro Conceição; Katell Le Goulven; Ronald U. Mendoza (eds.). Providing Global Public Goods: Managing Globalization. Oxford University Press, New York. DOI: $10.1093 / 0195157400.001 .0001$

Kelly, T., W. Yang, C-S. Chen, K. Reynolds \& J. He (2008). Global burden of obesity in 2005 and projections for 2030. International Journal of Obesity 32: 1431-37.

Kugelman, M. \& S. L. Levenstein (2013). The Global Farms Race: Land Grabs, Agricultural Investment and the Scramble for Food Security. Island Press.

Lagi, M., K.Z. Bertrand \& Y. Bar-Yam (2011). The Food Crises and Political Instability in North Africa and the Middle East. http://arxiv.org/pdf/1108.2455v1.pdf

Lang, T. (2003). Food Industrialisation and Food Power: Implications for Food Governance". Development Policy Review, 21 (5-6): 555-568.

Lopez-Gunn, E. B. Willaarts, A. Dumont, I. Niemeyer \& P. Martinez-Santos (2012). The concept of water and food security in Spain. In D’Estefano et al. Water, Agriculture and the Environment in Spain: Can We Square the Circle? Botin Foundation, Madrid.

MacMillan, A \& JL Vivero (2011). The governance of hunger. Innovative proposals to make the right to be free from hunger a reality. In: Martín-López, MA \& JL Vivero, eds. New challenges to the Right to Food. CEHAP, Cordoba and Editorial Huygens, Barcelona.

Magdoff, F. (2012). Food as a commodity. Monthly Review. Volume 63, Issue 08 (January). http://monthlyreview.org/2012/01/01/food-asa-commodity

Manno, J. P. (2002). Commoditization: Consumption Efficiency and an Economy of Care and Connection. In Confronting Consumption, eds. T. Princen, M. Maniates and K. Conca, pp. 67-100. MIT Press, Cambridge, MA.

Martínez, R. \& A. Fernández (2008). The cost of hunger: Social and economic impact of child undernutrition in Central America and the Dominican Republic. WFP-ECLAC, Santiago.

Maslow, A. (1943). A Theory of Human Motivation. Psychological Review, 50(4), 370-96.

Maxwell, S. (1997). A charter for food security. Food Policy 22, Issue 6, Pages 469-473

McClintock, J. (2010). The uniting of nations. An essay on global governance. Peter Lang, Brussels.

Messner E. \& M. Cohen (2008). "Conflict, food insecurity and globalization". En J. Von Braun y E. Díaz-Bonilla. Globalization of food and agriculture and the poor. Oxford University Press, New Delhi, India, págs. 299-366. 
Montanori, M. (2006). Food is culture. Arts and traditions on the table. Columbia University Press, New York.

Moodie, R. et al. (2013). Profits and pandemics: prevention of harmful effects of tobacco, alcohol, and ultra-processed food and drink industries. The Lancet - 12 February 2013. DOI: 10.1016/S0140-6736(12)62089-3

Morgan, D. (1979). Merchants of Grain. New York: Penguin Books.

Murray, S. (2007). Moveable Feasts: From Ancient Rome to the 21st Century, the Incredible Journeys of the Food We Eat. St. Martin's Press, New York.

Nature et Progrès (2012). Les groupes d'achats communs. Un partenariat entre producteurs et consommateurs pour produire et consommer autrement. Belgique http://www.groupesalimentaires.be/wp-content/uploads/Brochure-Groupes-dachat.pdf

Nuijten, Monique. (2006). Food Security, Technology, and the Global Commons 'New' Political Dilemmas? Focaal. 2006(48): v-vii.

OECD-FAO (2012). Agricultural Outlook 2012-2021. OECD, Paris \& FAO, Rome.

Ostrom, E. (1990) Governing the Commons: The Evolution of Institutions for Collective Action. Cambridge University Press, New York.

Ostrom, E. (2005). Understanding institutional diversity. Princeton University Press.

Ostrom, E. (2009). A polycentric approach to climate change. Policy Research working paper WPS 5095. World Bank, Washington, DC.

Ostrom, E. (2012). Green from the grassroots. Project Syndicate Commentry. http://www.project-syndicate.org/commentary/green-fromthe-grassroots\#czmrLHGBglhhU2P0.99

Ostrom, V. \& Ostrom, E. (1977). Public goods and public choices. In E.S. Savas, ed. Alternatives for delivering public services: toward improved performance. Boulder, Colorado, USA, Westview Press.

OXFAM (2012). Our land, Our lives. Time out on the global land rush. Oxfam Briefing Note, October. http://www.oxfam.org/sites/www.oxfam.org/files/bn-land-lives-freeze-041012-en_1.pdf

Pinstrup-Andersen, P. (2007). Eliminating Poverty and Hunger in Developing Countries: A Moral Imperative or Enlightened Self Interest? In Pinstrup-Andersen, P \& P. Sandøe, Peter (eds.). Ethics, Hunger and Globalization - in Search of Appropriate Policies. Pp. 15-27

Polaris Institute (2003). Global Water Grab: How Corporations are Planning to Take Control of Local Water Services. Ottawa.

Popkin, B.M. (2003). The nutrition transition in the developing world. Development Policy Review 21 (5-6): 581-597.

Prescott-Allen, R. \& Prescott-Allen, C. (1990), How Many Plants Feed the World? Conservation Biology, 4: 365-374. doi: 10.1111/j.15231739.1990.tb00310.x

Publico (2013). Agua, del derecho al negocio. 03 March 2013. http://www.publico.es/451517/agua-del-derecho-al-negocio

Quilligan, J. (2012). Why Distinguish Common Goods from Public Goods? In Bollier, D. \& S. Helfrich, eds. (2012). The Wealth of the Commons. A world beyond market \& state. Levellers Press. Amherst, MA. Abridged version available at http://p2pfoundation.net/Public Goods vs Common Goods

Raustiala, K. \& C. Sprigman (2012). The Knockoff Economy: How Imitation Sparks Innovation. Oxford University Press.

Rocha, C. (2007). Food Insecurity as Market Failure: A Contribution from Economics. Journal of Hunger and Environmental Nutrition. 1(4): $5-22$.

Rockström, J. et al (2009). A safe operating space for humanity. Nature 461, $472-475$ (24 September 2009) | doi:10.1038/461472a; Published online 23 September 2009

Rosset, P.M. (2006). Food is Different: Why the WTO Should Get out of Agriculture (Global Issues). Zed Books, London, UK

Samuelson, P.A. (1954). The Pure Theory of Public Expenditure. The Review of Economics and Statistics, Vol. 36, No. 4, pp. 387-389.

Sands, P. (2003). Principles of International Environment Law, Cambridge University Press, Second Edition

Scholte, J.A. (2005). The Sources of Neoliberal Globalization. UNRISD Overarching Concerns Programme Paper 8, Geneve. http://www.unrisd.org/80256B3C005BCCF9/\%28httpAuxPages\%29/9E1C54CEEB19A314C12570B4004D0881/\$file/scholte.pdf

Serra, J. et al. (2012). Measuring the Evolution of Contemporary Western Popular Music. Scientific Reports 2, 521. doi:10.1038/srep00521

Shah, A. (2009). Media Conglomerates, Mergers, Concentration of Ownership. Global Issues, 02 January 2009.

http://www.globalissues.org/article/159/media-conglomerates-mergers-concentration-of-ownership 
Sidel, V.W. (1997). The public health impact of hunger. Am J Public Health. 1997 December; 87(12): $1921-1922$.

Stallman, R. (2012). The free software definition. http://www.gnu.org/philosophy/free-sw.en.html

Stavenhagen, R. (2003). Needs, Rights and Social Development. Overarching Concerns Programme Paper Number 3. UNRISD, Geneva.

Stevens, G., G. Singh, G. Danaei et al. (2012). National, regional and global trends in adult overweight and obesity prevalences. Population Health Metrics 10 (22): 1-16.

Stuart, T. (2009). Waste: uncovering the global food scandal. Penguin Books, London.

Swedish Board of Agriculture (2013). Sustainable meat consumption: What is it? How do we get there? Stockholm. http://www.jordbruksverket.se/download/18.5df17f1c13c13e5bc4f800039403/En+h\%C3\%A5Ilbar+k\%C3\%B6ttkonsumtion.pdf

The Economist (2009). Universal health insurance is a common good. 8 October 2009.

http://www.economist.com/blogs/democracyinamerica/2009/10/universal health insurance is

The Food Commons (2011). The Food Commons 2.0. Imagine, design, build. October 2011.

http://www.thefoodcommons.org/images/FoodCommons 2-0.pdf

The Jamaica Observer (2011). The right to breathe fresh air. 02 March 20111. http://www.jamaicaobserver.com/columns/The-right-tobreathe-fresh-air_8453339\#ixzz264bVFCJU

UK Government (2011). The future of food and farming: challenges and choices for global sustainability. Final project report. Foresight, Department for Business Innovation and Skills. The Government Office for Science, London.

UNEP (2009). The environmental food crisis. The environment's role in averting future food crises. United Nations Environmental Programme, Nairobi.

UNICEF (2011). Levels and trends in child mortality. UN Inter-agency Group for Child Mortality Estimation, New York.

United Nations (1948). Universal Declaration of Human Rights. General Assembly Resolution 217 A (III). UN Doc. A/810, at 71 (1948))

United Nations (1966). International Covenant on Economic, Social and Cultural Rights, adopted on 16 December 1966 , General Assembly Resolution 2200(XXII), UN. GAOR, 21st sess., Supp. No. 16, U.S. Doc. A/6316 (1966), 993 UNTS 3.

United Nations (2005). Halving Hunger: It can be done. Report of the Task Force on Hunger of the UN Millennium Project. http://www.unmillenniumproject.org/documents/HTF-SumVers FINAL.pdf

United Nations (2010). Sixty-fourth General Assembly Plenary resolution. GA/10967

http://www.un.org/News/Press/docs/2010/ga10967.doc.htm

Unnevehr, L.J. (2006). Food Safety as a Global Public Good: Is There Underinvestment? Plenary paper prepared for presentation at the International Association of Agricultural Economists Conference, Gold Coast, Australia, August 12-18, 2006.

http://ageconsearch.umn.edu/bitstream/25733/1/pl06un01.pdf

Van Parijs, P. (2005). Basic income. A simple and powerful idea for the twenty-first century. http://www.uclouvain.be/cps/ucl/doc/etes/documents/Chap1.Simple and Powerful.pdf

Ver Eecke, W. (1999). Public Goods: An Ideal Concept. Journal of Socio-Economics 28: 139-156.

Von der Hoeven, R. (2012). MDGs post 2015: Beacons in turbulent times or false lights? Background paper was prepared for the UN System Task Team on the Post-2015 UN Development Agenda. http://www.un.org/en/development/desa/policy/untaskteam undf/rolph van der hoeven.pdf

Walljasper, J. (2011). Celebrating all we share three times a day. On the Commons Magazine. http://www.onthecommons.org/magazine/celebrating-all-we-share-three-times-day

Weis, T. (2007). The global food economy. The battle for the future of farming. Zed books, London.

WHO (2002). Global public goods for health: the report of Working Group 2 of the Commission on Macroeconomics and Health. Geneva.

Wise, T.A. \& S. Murphy (2012). Resolving the Food Crisis: Assessing Global Policy Reforms Since 2007. Global Development and Environment Institute and the Institute for Agriculture and Trade Policy. Medford, Mass. http://www.ase.tufts.edu/gdae/Pubs/rp/ResolvingFoodCrisis.pdf?utm source=SRFood+Newsletter\&utm campaign=e512da1b14-2012-

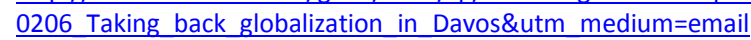

Wolf, M. (2012). The world's hunger for public goods. Financial Times, 24 January 2012. http://www.ft.com/cms/s/0/517e31c8-45bd-11e193f1-00144feabdc0.html\#axzz2OlUVOTof

World Bank (2006). Repositioning nutrition as central to development. A strategy for large-scale action. Washington, DC. 
World Bank (2008). World development report 2008: Agriculture for development. Washington, DC.

World Bank (2012). Global Monitoring Report 2012: Food Prices, Nutrition and the MDGs. Washington D.C.

WEF (2013). Achieving the New Vision for Agriculture. New models for action. The World Economic Forum, Davos, Switzerland.

Wright, E.O. (2010). Envisioning Real Utopias. Verso, London.

Young, O. R. (2003). Taking Stock: Management Pitfalls in Fisheries Science. Environment 45 (3).

\section{Additional references that could be included in the paper later on}

Anderson, C. L. (1991), Nature vs. Nurture: Systems of Property Rights in First Peoples, presented at the second annual conference of the International Association for the Study of Common Property, Winnipeg, Manitoba.

Brousseau, E., T. Dedeurwaerdere et al. (2012). Global environmental commons: analytical and political challenges in building governance mechanisms. Oxford University Press, Oxford, UK.

Carolan, M. (2012). The sociology of food and agriculture. Routledge, UK.

Castree, N. (2003). Commodifying what nature? Prog Hum Geogr 2003 27: 273. DOI: 10.1191/0309132503ph428oa

Common Property Conference, the Second Biennial Conference of the International Association for the Study of Common Property. Winnipeg, Manitoba, September 26-29, 1991

Earl, P.E. \& J. Potts (2011). A Nobel Prize for Governance and Institutions: Oliver Williamson and Elinor Ostrom. Review of Political Economy Review vol. 23(1), pages 1-24.

Griffin, K. (2003). Economic Globalization and Institutions of Global Governance. Development and Change, 34, 5, 789-807.

Heater, D. (2002). World Citizenship. Continuum, London.

Held, D. (2004). Global Covenant. Polity Press, Cambridge, MA.

Lang, T. and Heasman, M. (2004), Food Wars: The Global Battle for Mouths, Minds and Markets, London, Earthscan.

Mehta, L. (2003). Problems of publicness and access rights: perspectives from the water domain. In Inge Kaul; Pedro Conceição; Katell Le Goulven; Ronald U. Mendoza (eds.). (2003). Providing Global Public Goods: Managing Globalization. Oxford University Press, New York. DOI: $10.1093 / 0195157400.001 .0001$

Ostrom, E. (2000). "Private and Common Property Rights", in Encyclopedia of Law and Economics, Vol. II: Civil Law and Economics, pages 332-379. Ghent, Belgium: University of Ghent. http://www.sfu.ca/ allen/common\%20property.pdf

Pogge, T. (2012). Poverty, human rights and the global order : framing the post-2015 agenda. http://www.crop.org/viewfile.aspx?id=401

Reeson, A.F. (2008). Institutions, Motivations and Public Goods: Theory, Evidence and Implications for Environmental Policy, No 2008-01, Socio-Economics and the Environment in Discussion (SEED) Working Paper Series, CSIRO Sustainable Ecosystems, http://EconPapers.repec.org/RePEc:cse:wpaper:2008-01.

Van Dam, D., M. Streith, Jean Nizet et P. M. Stassart. (2012). Agroecologie. Entre practiques et sciences sociales. Educagri editions, Dijon.

Vivero, J.L. (2012). A binding Food Treaty : a post-MDG proposal worth exploring. Memo 173, Fundacion Alternativas, Madrid. http://www.falternativas.org/opex/documentos/memorandos/a-binding-food-treaty-a-post-mdg-proposal-worth-exploring

WHO (2011). Global Status Report on Non-communicable Diseases 2010. World Health Organization, Geneva. 